(C) В.О. Сипливий, Д.В. Свтушенко, О.В. Свтушенко, В.В. Доценко, 2018

УДК 616.336.7-06-089-035

\title{
Хірургічне лікування ускладнень холелітіазу
}

\author{
В.О. Сипливий, Д.В. Свтушенко, О.В. Свтушенко, В.В. Доценко \\ syplyviy@ukr.net
}

Харківський національний медичний університет, кафедра загальної хірургї № 2, Харків

\section{Реферат}

Мета дослідження. Аналіз результатів хірургічного лікування хворих з ускладненнями холелітіазу.

Матеріали та методи. Робота базується на аналізі результатів хірургічного лікування 184 хворих з ускладненнями холелітіазу. Чоловіків було 68 (37\%), жінок - 116 (63\%). Вік хворих коливався від 31 до 88 років і в середньому становив $64,1+1,0$ року.

Результати досліджень та їх обговорення. Основним методом відновлення жовчотоку у пацієнтів з холедохолітіазом та обтураційною жовтяницею було ендоскопічне транспапілярне втручання - ЕПСТ з літекстракцією. Дане втручання проведено 105 хворим. У 89 (84,7 \%) пацієнтів ЕПСТ була одномоментним втручанням. У 9 (8,6 \%) пацієнтів проведено повторне успішне ендоскопічне втручання. У 7 (6,7 \%) пацієнтів ендоскопічна корекція жовчотоку була безуспішною і їм виконано відкрите оперативне втручання. Післяопераційні ускладнення спостерігалися у 16 (15,2\%) пацієнтів: Grade 1-2 за Clavien-Dindo відзначені у 13 (12,38 \%) пацієнтів, Grade 3b - у 3(2,85 \%). Найбільш частим ускладненням післяопераційного періоду були гострий панкреатит і кровотеча із папілотомної рани (по 6 випадків).

Групу хворих з холангітом за критеріями Tokyo Guidelines 2013 склали 62 пацієнти. Тяжкий холангіт, що супроводжувався органною дисфункцією, виявлено у 3 (4,8\%) хворих, середній ступінь - у 26 (41,9\%), у решти 33 $(53,3 \%)$ хворих - холангіт першого ступеня тяжкості. У пацієнтів з холангітом II-III ступеня тяжкості із жовчі було виділено E. coli, P. aeruginosa, K. pneumoniae. ЕПСТ з літекстракцією виконано у 29 пацієнтів. ЕПСТ була успішною у $22(75,9 \%)$ пацієнтів. У 40 пацієнтів виконано відкриті втручання з одномоментним відновленням жовчотоку. У 10 (25\%) пацієнтів конкременти холедоха видалені шляхом холедохотомії з подальшим швом холедоха. У 20 (50\%) пацієнтів 3 явищами гнійного холангіту холедохолітотомію завершено зовнішнім дренажем холедоха. У 10 (25 \%) пацієнтів виконано внутрішнє дренування жовчної протоки: у 5 - накладено холедоходуоденоанастомоз, у 5 - гепатикоєюноанастомоз за Roux-en-Y у нашій модифікації.

Синдром Mipiззі за класифікацією Beltran and Csendes (2008) було діагностовано у 34 хворих. Всі хворі відзначали тривалий перебіг ЖКХ з багаторазовими больовими нападами. 14 надійшло 3 клінікою гострого холециститу, у 5 ускладненого формуванням підпечінкового або піддіафрагмального абсцесів, у 1 - абсцесу печінки. 18 хворих надійшло 3 клінікою обтураційної жовтяниці, холедохолітіазу на тлі гострого холециститу, 2 - 3 клінікою непрохідності тонкої кишки.

Висновки. Гострий холангіт розвивається у 33,7 \% хворих, 3 них першого ступеня - у 53,3 \%, другого - у 41,9 \%, третього (тяжкого) ступеня - у 4,8 \% з субкомпенсацією або декомпенсацією функції щонайменше однієї системи організму у 46,7 \% хворих. Аналіз інтраопераційних змін свідчить про те, що з переходом від першого типу синдрому Міріззі до п'ятого збільшується ступінь морфологічних змін, що характеризуються облітерацією трикутника Кало, 3 порушенням анатомії та цілісності структур даної зони з розвитком холецистобіліарної або холецистодигесивної нориць.

Ключові слова: холелітіаз, холедохолітіаз, обтураційна жовтяниця, гострий холангіт, синдром Міріззі, хірургічне лікування

\section{Surgical treatment of cholelithiasis complications}

Syplyviy V., Ievtushenko D., Ievtushenko O., Dotcenko V.

Kharkiv national medical university, general surgery department №2, Kharkiv

\section{Abstract
The aim of the work was to provide the analysis of surgical treatment for patients with cholelithiasis complications.}

Materials and methods. 184 patients were included. Men - 68 (37\%), women $116(63 \%)$. The male to female ratio 1 : 1.7. The average age was $64,1+1,0$ years, ranged from 31 to 88 .

Results. Endoscopic sphincterotomy was performed in 105 patients with choledocholithiasis and obstructive jaundice. In $89(84.7 \%)$ patients primary EPST was successful, $9(8.6 \%)$ patients underwent successful second intervention. In $7(6.7 \%)$ patients an open surgery was performed. Recovery of bile flow leads to normalization of bilirubin levels, AST and ALT remains increased. Acute cholangitis diagnosed in $62(33,7 \%)$ patients. All patients underwent surgical treatment. All patients classified according Tokyo Guidelines 2013 - acute cholangitis of first $-53.3 \%$, second - $41.9 \%$ and third (severe) $-4.8 \%$. Recovery of bile duct leads to normalization of bilirubin levels, but the activity of cytolytic enzymes (AST and ALT) remains high. Postoperative complications were observed in $16(15,2 \%)$ patients: Grade 1-2 (Clavien-Dindo) - in 13 $(12,38 \%)$ patients, Grade $3 b$ - in $3(2,85 \%)$. Acute pancreatitis and bleeding from the papillotomy incision were the most common complications. E. coli, P. aeruginosa, K. pneumoniae isolated from bile in patients with mild or severe cholangitis. EPST was performed in 29 patients, was successful in $22(75.9 \%)$ patients. Open surgery was performed in 40 patients: 10 (25\%) patients - cholecystectomy with choledochotomy for stone extraction; in 20 (50\%) patients- external drainage of CBD. In 10 (25\%) patients internal drainage performed: in 5 cases, choleldochoduodenostomy, in 5 - hepaticojejunostomy in our modification. Mirizzi syndrome (Beltran and Csendes,2008) diagnosed in 34 patients (third group). The analysis of the results of diagnostics and surgical treatment of Mirizzi syndrome showed that of 34 patients with Mirizzi syndrome, 14 came with signs of acute cholecystitis, 5 - complicated by the formation of subhepatic or subdiphragmic abscesses, 1 - abscess of 
the liver. 18 came with dominant simptoms of obstructive jaundice and cholecystitis, and 2 - with an obstruction of the small intestine. All patients noticed recurrent pain attacts during longgoing disease.

Conclusion. Acute cholangitis developed in $33,7 \%$ of patients with obstructive jaundice caused by choledocholithiasis. Severity (according to Tokyo Guidelines 2013 criteria) - first degree $-53.3 \%$, second $-41.9 \%$, the third (severe) - $4.8 \%$. Subcompensation or decompensation of at least one body system occurs in $46.7 \%$ of patients. Cholangitis leads to significant changes in peripheral blood, disturbances of the liver function, which persist after the bile flow reparation. The degree of local morphological changes increases from the first type of Mirizzi syndrome to the fifth, obliteration of the Calot's triangle occurs. Such changes lead to the development of cholecystobiliary or cholecystoenteric fistula.

Key words: cholelithiasis, choledocholithiasis, obstructive jaundice, acute cholangitis, Mirizzi syndrome, surgical treatment

Вступ. Холелітіаз $є$ одною $з$ найбільш розповсюджених та значущих хвороб сучасного суспільства. На холелітіаз у розвинених країнах страждає $10-15 \%$ чоловіків та $25 \%$ жінок, при цьому число хворих на холелітіаз кожні 10 років збільшується у 2 рази [1], що супроводжується збільшенням частоти його ускладнених форм. При цьому переважний процент таких пацієнтів складають хворі похилого віку $[2,3]$.

Холедохолітіаз, як ускладнення холелітіазу, трапляється у 20-30 \% випадків. Від $21 \%$ до $34 \%$ конкрементів загальної жовчної протоки спонтанно мігрують, і ці конкременти призводять до немалого ризику розвитку панкреатиту чи холангіту [4]. Частота розвитку гострого холангіту при холедохолітіазі становить $66,4-88,1 \%[5,6]$. Перебіг холелітіазу, особливо під час загострення, характеризується розвитком цілого комплексу ускладнень у системі «жовчний міхур - жовчні протоки печінка - підшлункова залоза», значна кількість хворих оперується у гострій стадії або після iï затихання [7]. Частина хворих не оперується у зв'язку з наявністю супутніх захворювань, похилого або старечого віку, ризиком анестезії, що призводить до розвитку ускладнень, таких як синдром Міріззі, частота яких складає $0,7-14 \%[5,8,9]$.

Тому на сьогодні залишається актуальним питання діагностики ускладнень холелітіазу, розробки індивідуалізованої програми їх хірургічного лікування.

Мета дослідження. Аналіз результатів хірургічного лікування хворих з ускладненями холелітіазу.

Матеріали та методи. Робота базується на аналізі результатів хірургічного лікування 184 хворих 3 ускладненнями холелітіазу. Чоловіків було 68 (37\%), жінок - 116 (63\%). Вік хворих коливався від 31 до 88 років і в середньому становив $64,1+1,0$ рік. Проведено аналіз результатів лікування таких ускладнень холелітіазу: холедохолітіаз та обтураційна жовтяниця (перша група), гострий холангіт (друга група), синдром Міріззі (третя група). Для обстеження хворих використовували клініколабораторні, біохімічні, інструментальні, морфологічні методи дослідження. Для підтвердження діагнозу гострого холангіту та визначення тяжкості стану використовувалися критерії Tokyo Guidelines 2013. Для аналізу і класифікації післяопераційних ускладнень використовувалася шкала Clavien-Dindo [10]. Статистична обробка даних проводилася за допомогою ліцензованих програмних продуктів - Statistica 10.0 for Windows.

Результати досліджень та їх обговорення. Основним методом відновлення жовчотоку у пацієнтів 3 холедохолітіазом та обтураційною жовтяницею було ендоскопічне транспапілярне втручання ЕПСТ з літекстракцією. Дане втручання проведено 105 хворим. У 89 (84,7 \%) пацієнтів ЕПСТ була одномоментним втручанням. У 9 (8,6 \%) пацієнтів унаслідок розвитку кровотечі із папілотомної рани ендоскопічне втручання було зупинено, а через 3-5 діб, після стабілізації стану хворих було проведено повторне успішне ендоскопічне втручання. У 98 (93,3\%) пацієнтів було досягнуто видалення конкрементів, які викликали обструкцію, та відновлено прохідність жовчної протоки. У 7 (6,7 \%) пацієнтів ендоскопічна корекція жовчотоку була безуспішною і їм виконане відкрите оперативне втручання. Другим етапом лікування 30 пацієнтам виконана лапароскопічна холецистектомія на 3-4-ту добу після корекції жовчотоку та зниження загального білірубіну до рівня, нижчого за 1,5 ULN. У 3 пацієнтів холецистектомія була доповнена зовнішнім дренажем холедоха через куксу міхурової протоки.

Розвиток обтураційної жовтяниці при холедохолітіазі супроводжується змінами картини периферичної крові, що проявляється помірним лейкоцитозом $\left(8,1 \pm 0,39 \times 10^{9} /\right.$ л $), 3$ коливанням показників від 2,8 до $26,3 \times 10^{9} /$ л, зсувом лейкоформули вліво, що відображає загальну запальну реакцією організму хворих. Нами не виявлено достовірної різниці у реакції крові $з$ асимптомним холедохолітіазом та холедохолітіазом $з$ обтураційною жовтяницею. Ці дані можна пояснити тим, що зміни лейкоформули обумовлені запальними змінами у жовчному міхурі і не пов'язані з розвитком обтураційної жовтяниці. Відновлення жовчотоку супроводжувалось реакцією системи крові, що проявлялась на 1 добу зниженням кількості еритроцитів i лімфопенією, пов'язаних 3 операційною агресією, 3 нормалізацією показників до 3-5 доби. Одночасно спостерігали значне зниження рівня загального білірубіну до $34,7 \pm 4,5$ мкмоль/л. Але активність цитолітичних ферментів АЛТ $(318,2 \pm 42,6$ Од\Л) і АСТ $(139,2 \pm 16$ Од\л) залишалась високою. Це свідчить про необхідність проведення спрямованої гепатотропної терапії у післяопераційному періоді.

Післяопераційні ускладнення спостерігалися у 16 (15,2 \%) пацієнтів: Grade 1-2 за Clavien - Dindo відзначені у $13(12,38 \%)$ пацієнтів, Grade $3 \mathrm{~b}-\mathrm{y}$ 
3 (2,85 \%). Найбільш частим ускладненням післяопераційного періоду були гострий панкреатит і кровотеча із папілотомної рани (по 6 випадків).

Всі три критерії A, B, C Tokyo Guidelines 2013 виявлено у 62 (33,7\%) пацієнтів, які склали групу хворих із холангітом. У 23 хворих виявлено по дві ознаки TG13, які трактувалися як підозра на холангіт.

Важкий холангіт, що супроводжується органною дисфункцією, виявлено у $3(4,8 \%)$ хворих, середня ступінь тяжкості - у $26(41,9 \%)$, у решти $33(53,3 \%)$ хворих - холангіт першого ступеня тяжкості. У пацієнтів з холангітом II-III ступеня тяжкості із жовчі було виділено E. coli, P. aeruginosa, K. pneumoniae. Розвиток холангіту супроводжується змінами картини периферійної крові, що проявляються підвищенням кількості лейкоцитів до $12,4 \pm 0,7 \times 10^{9} /$ л $(\mathrm{p}<0,05) \quad 3$ коливаннями від 4 до $34,2 \times 10^{9} /$ л, зсувом лейкоформули вліво. Одночасно спостерігаються зміни функціональних проб печінки. Рівень загального білірубіну підвищувався до $116,0 \pm 10,7$ мкмоль/л $(\mathrm{p}<0,05)$ і коливався від 14,8 до 336 ммоль/л. Значно зростала активність цитолітичних ферментів - АЛТ до 221,5 \pm 21 Од/л $(\mathrm{p}<0,05)$ з коливанням від 20 Од/л до 973 Од/л; АСТ до $139,9 \pm 13,8$ Од/л $(\mathrm{p}<0,05)$ з коливанням від 12 Од/л до 400 Од/л.

За критеріями Common terminology criteria y $37(59,6 \%)$ хворих рівень загального білірубіну перевищував верхню межу норми більше ніж у 3 рази, що відповідає тяжкому чи вкрай тяжкому рівню порушень і пов'язаний з високим ризиком ускладнень. Активність АЛТ у 45,8 \%, АСТ у 18 \% пацієнтів перевищували 200 Од/л, що відповідає тяжким/загрожуючим життю змінам. Після відновлення жовчотоку протягом перших трьох діб залишався підвищенй рівень лейкоцитів крові зі збереженням зсуву формули крові вліво, що обумовлено гострим холангітом. Зменшення запальних змін лейкоформули крові спостерігалось тільки з 4-7 доби після операції. Динаміку змін лейкоформули відображала і динаміка гематологічних індексів.

Відновлення жовчотоку супроводжувалось зменшенням порушень функціональних показників печінки. Рівень загального білірубіну значно знижувався на 4-5 добу після оперативного втручання, але активність цитолітичних ферментів АЛТ і АСТ залишалась високою і на час виписки хворих зі стаціонару.

Ускладнення у післяопераційному періоді виникли у 12 хворих хворих з гострим холангітом. У 3 із 12 хворих ускладнення потребували виконання лапаротомних операцій (Grade 3B), у одного став летальний кінець (Grade5).

Синдром Міріззі за класифікацією Beltran and Csendes (2008) було діагностовано у 34 хворих. Синдром Міріззі I діагностовано у 6 пацієнтів. Хворі оперовані відкритим способом - виконано холецистектомію, в одному випадку доповнену зовнішнім дренажем холедоха у зв'язку з клінічними проявами холангіту. Синдром Міріззі II діагностовано у 9 пацієнтів. В усіх випадках проведено пластику холецистобіліарної нориці, у 6 - доповнену зовнішнім дренажем холедоха, а в 1 пацієнта накладено холедоходуоденоанастомоз. Синдром Міріззі III діагностовано у 4 пацієнтів. У 3 хворих виконано субтотальну холецистектомію, в 1 - холецистектомію від дна. У 2 хворих проведено пластику нориці з використанням стінки жовчного міхура, в 1 випадку доповнену зовнішнім дренажем холедоха, 2 хворим накладено гепатикоеюноанастомоз за Ру у нашій модифікації. Синдром Міріззі IV діагностовано у 5 пацієнтів. Виконано субтотальну холецистектомію. 4 пацієнтам проведено пластику біліарної нориці з використанням тканин міхура, доповнену зовнішнім дренажем холедоха у 3 випадках. В 1 хворого сформовано гепатикоєюноанастомоз за нашою методикою. Синдром Miрiззі Vа типу діагностований у 8 хворих, 3 них 4 (50\%) пацієнти надійшли 3 клінікою гострого деструктивного холециститу з формуванням підпечінкового, а у 2 - і піддіафрагмального абсцесів. У всіх випадках виявлено холецистодуоденальну норицю. Усім 4 хворим виконано субтотальну холецистектомію, пластику холецистобіліарної нориці, пластику нориці дванадцятипалої кишки. 4 (50\%) пацієнти надійшли з симптомами обтураційної жовтяниці, без виражених проявів гострого запального процесу. Як перший етап у 3 хворих виконано ЕПСТ із санацією жовчної протоки. Другим етапом у 1 пацієнта проведено лапароскопічне втручання - кліпування міхурово-дуоденальної нориці, 2 - відкрите втручання. В одному випадку виявлено холецисто-товстокишкову норицю, у другому - холецистодуоденальну норицю. Виконано субтотальну холецистектомію, пластику холецисто-біліарної та ентеральної нориць, зовнішнє дренування холедоха. В 1 пацієнта проведено відкрите втручання - субтотальну холецистектомію 3 видаленням конкрементів жовчної протоки через норицю, пластику холецисто-біліарної нориці, сформовано холедоходуоденоанастомоз. Для анастомозу використано зону дефекту дванадцятипалої кишки після висічення змінених тканин стінки кишки. Синдром Міріззі Vб типу діагностовано у двох хворих. Хворі надійшли з клінікою високої гострої непрохідності тонкої кишки, у тяжкому стані, в одному випадку 3 явищами ендотоксичного шоку. На операції виявлено великі конкременти (4 і 5 см в діаметрі), які обтурували просвіт кишки. Виконано ентеротомію, видалення конкрементів.

Аналіз результатів діагностики і хірургічного лікування синдрому Міріззі показав, що з 34 хворих із синдромом Міріззі 14 надійшло з клінікою гострого холециститу, у 5 - ускладненого формуванням підпечінкового або піддіафрагмального абсцесів, у 1 абсцесу печінки. 18 хворих надійшло з клінікою обтураційної жовтяниці, холедохолітіазу на тлі гострого холециститу, 2 - 3 клінікою непрохідності тонкої кишки. Всі хворі відзначали тривалий перебіг ЖКХ 3 багаторазовими больовими нападами. 
Висновки. 1. Мініінвазивне лікування $є$ ефективним у 93,2 \% пацієнтів 3 клінікою обтураційної жовтяниці при холедохолітіазі, у 8,5 \% супроводжується розвитком ускладнень, а у $6,4 \%$ є безуспішним.

2. Гострий холангіт розвивається у 33,7 \% хворих, 3 них першого ступеня - у 53,3 \%, другого - у 41,9 \%, третього (тяжкого) ступеня - у 4,8 \% 3 субкомпенсацією або декомпенсацією функції щонайменше однієї системи організму у 46,7 \% хворих.
3. Аналіз інтраопераційних змін свідчить про те, що 3 переходом від першого типу синдрому Міріззі до п’ятого збільшується ступінь морфологічних змін в системі печінка - жовчний міхур жовчна протока - дванадцятипала кишка, що характеризуються облітерацією трикутника Кало, 3 порушенням анатомії та цілісності цілісності структур даної зони з розвитком холецистобіліарної або холецистодигесивної нориць.

Інформація про конфлікт інтересів. Автори заявляють про відсутність конфлікту інтересів при виконанні наукового дослідження та підготовці даної статті.

Інформація про фінансування. Автори гарантують, що вони не отримували жодних винагород в будь-якій формі, здатних вплинути на результати роботи.

Особистий внесок кожного автора у виконання роботи:

В.О. Сипливий - загальна ідея дослідження;

Д.В. Свтушенко - набір клінічного матеріалу та аналіз результатів;

О.В. Свтушенко - статистична обробка даних;

В.В. Доценко - аналіз отриманих результатів.

\section{Список використаної літератури}

1. Mullhaupt B. Natural History and Pathogenesis of Gallstones. In: Clavien PA, Baillie J. Diseases of the Gallbladder and Bile Ducts: Diagnosis and Treatment. Blackwell Publishing Ltd : Oxford;2007: 216-28.

2. Novacek G. Gender and gallstone disease. Wien Med Wochenschr. 2006;156(19-20):527-33. Available from: https://link.springer.com/article/ DOI: 10.1007/s10354-006-0346-x.

3. Zaporozhchenko BS, Kolodii VV, Horbunov AA, Muraviov PT, Bondarets DA. Dyferentsiiovanyi pidkhid do vyboru metodu likuvannia uskladnenoi zhovchnokamianoi khvoroby u patsiientiv starshoi vikovoi hrupy. Visnyk Vinnytskoho natsionalnoho medychnoho universytetu. 2017;№1, ch.1(T.21):. 125-9 [In Ukrainian].

4. Nychytailo ME, Ohorodnyk PV, Deinychenko AH, Boiko OH, Khrystiuk DY. Mynyynvazyvnыe khyrurhycheskye vmeshatelstva pry obturatsyy dystalnoho otdela obshcheho zhelchnoho protoka. Khirurhiia Ukrainy. 2012;(4):16-20. [In Ukrainian].

5. Beltran MA, Csendes A, Cruces KS. The relationship of Mirizzi syndrome and cholecystoenteric fistula: validation of a modified classification. World J Surg 2008;32(10):2237-43 Available from: https://www.ncbi.nlm.nih.gov/pubmed/18587614 DOI: 10.1007/s00268-008-9660-3.

6. Syplyviy VA, Ievtushenko DV, Petrenko HD, Andreeshchev SA, Ivtushenko AV. Khyrurhycheskoe lechenye ostroho kholanhyta pry kholedokholytyaze. Klinichna khirurhiia. 2016;(1):34-7. [In Ukrainian].

7. Kondratenko PH, Konkova MV, Belozertsev OA, Yudyn AA. Khyrurhycheskaia taktyka u bolnыkh pozhyloho y starcheskoho vozrasta $\mathrm{s}$ ostrum kholetsystytom y obturatsyonnoi zheltukhoi. Khirurhiia Ukrainy.2007;22(2):27-30. [In Ukrainian].

8. Rusyn VI, Rusyn AV, Rumiantsev KI. Spontanni vnutrishni biliarni norytsi. Visnyk morskoi medytsyny. 2001;14(2):299-302. [In Ukrainian].

9. Syplyviy VA, Ievtushenko DV, Petrenko HD, Andreeshchev SA, Ievtushenko AV. Dyahnostyka y khyrurhycheskoe lechenye syndroma Mirizzi. Klinichna khirurhiia. 2016;(8):8-11. [In Ukrainian].

10. Dindo D, Demartines N, Clavien PA. Classification of surgical complications a new proposal with evaluation in a cohort of 6336 patients and results of a survey Ann Surg. 2004;240(2):205-13. PubMed PMID: 15273542 PMCID: PMC1360123.

Стаття надійшла до редакції: 19.01 .2018 р. 